\title{
Human Papillomavirus Prevalence among Women with Cervical Intraepithelial Neoplasia III and Invasive Cervical Cancer from Goiânia, Brazil
}

\author{
SH Rabelo-Santos, L Zeferino*/+, LL Villa**, JP Sobrinho ${ }^{* *}$, RG Amaral, AV Magalhães***
}

Faculdade de Farmácia, Universidade Federal de Goiás, Goiânia, GO, Brasil *Departamento de Tocoginecologia, Centro de Atenção Integral à Saúde da Mulher, Universidade Estadual de Campinas, Rua Alexander Fleming 101,13083-970 Campinas, SP, Brasil **Instituto Ludwig de Pesquisa sobre o Câncer, São Paulo, SP, Brasil ***Departamento de Patologia, Universidade de Brasília, Brasília, DF, Brasil

This study estimated the prevalence and distribution of human papillomavirus (HPV) types among women with cervical intraepithelial neoplasia (CIN) grade III and invasive cervical cancer from Goiás (Brazil Central Region). Seventy-four cases were analyzed and consisted of 18 CIN III, 48 squamous cell carcinomas, 4 adenocarcinomas, 1 adenosquamous carcinoma and 3 undifferentiated carcinomas. HPV-DNA sequences were examined in formalinfixed and paraffin-embedded tissues using primers from L1 region GP5+/GP6+. Polymerase chain reaction products were typed with dot blot hybridization using probes for HPV 16, 18, 31, 33, 45, 54, 6/11, 42/43/44, 51/52, 56/ 58. The prevalence of HPV was estimated to be $76 \%(56 / 74)$. HPV 16 was the most frequently found type, followed by HPV 33, 18 and 31. The prevalence of untyped HPV was 6\%; 79\% percent of the squamous cell carcinoma cases and $61 \%$ percent of the CIN III were positive for HPV and the prevalence rate of HPV types was the same for the total number of cases. According to other studies, HPV type 16 is the most prevalent virus in all Brazilian regions, but there is variation regarding to other types. Type 18 is the second most prevalent HPV in North, Southeast and South Brazil regions and types 31 and 33 are the second most prevalent HPV in Northeast and Central Brazil, respectively.

Key words: human papillomavirus - cervical cancer - cervical intraepithelial neoplasia - polymerase chain reaction dot blot hybridization - prevalence - Goiás - Brazil

Many epidemiological studies indicate that human cancer is a multifactorial disease, which can develop through different molecular biologic pathways. Currently there is compelling evidence that the development of human cervical cancer without the involvement of the specific human papillomavirus (HPV) is exceptional or impossible (Walboomers \& Meijer 1997).

The International Biological Study on Cervical Cancer demonstrated that $92.9 \%$ of cervical cancer from 22 countries contained HPV-DNA, ranging from 75 to $100 \%$ (Bosch et al. 1995). Variations in HPV-DNA prevalence are highly dependent on the technique used. A higher prevalence is assayed by polymerase chain reaction (PCR) than by other methods (de Roda Husman et al. 1995, Syrjanen \& Syrjanen 2000). Walboomers et al. (1999) showed that HPV is present in $99.7 \%$ of patients with invasive cervical cancer, when PCR based and serologic assays were used. Evidence suggests that the HPV E6 oncoprotein can bind to $\mathrm{p} 53$ protein and promote its degradation which is consistent with the low frequency of p53 mutation reported in these tumor as compared with other cancers (Pinheiro $\&$ Villa 2001).

Studies of Brazilian women showed that HPV DNA prevalence in invasive cervical cancer ranged from $55.2 \%$

${ }^{+}$Corresponding author. Fax: + 55-19-3289.5935. E-mail: zeferino@ caism.unicamp.br

Received 15 May 2002

Accepted 27 November 2002 when using non-isotopic in-situ hybridization to $91 \%$ when using PCR-based assays (Cavalcanti et al. 1994, 2000, ElufNeto et al. 1994, Bosch et al. 1995, Gonçalves et al. 1999, Noronha et al. 1999, Lorenzato et al. 2000).

The prevalence of HPV types found in cervical cancer shows worldwide geographical variations (Bosch et al. 1995). In Brazil, a country with almost continental proportions, studies of HPV prevalence in cervical cancer from four of its five regions are available. All these published studies showed that HPV 16 is the predominant type in cities of the Northern, Northeast, Southeast and Southern regions, although there are regional variations with regard to other types (Cavalcanti et al. 1994, Eluf-Neto et al. 1994, Bosch et al. 1995, Gonçalves et al. 1999, Noronha et al. 1999, Lorenzato et al. 2000).

In the Central Region of Brazil, cervical cancer is the second most common malignancy, with the exclusion of skin cancer, and is the second most common cause of death among women (Brasil 2001). However, no information regarding HPV-DNA prevalence and distribution is available. Thus, the aim of our study was to determine the prevalence of different HPV types among women with cervical intraepithelial neoplasia (CIN III) and invasive cancer from Goiânia, a city situated in Central Brazil.

\section{MATERIALS AND METHODS}

Eighty-six cases of CIN III and invasive cervical cancer were initially included in this study. All samples were obtained from patients who had undergone hysterectomy at Araújo Jorge Hospital in the city of Goiânia (State of Goiás) between November 1997 and November 1998. Tu- 
mor tissues were fixed in buffered formalin during 14 to 18 $\mathrm{h}$ and embedded in paraffin. Serial sections from each block were made: the first sections were stained with haematoxylin-eosin to be histopathologically examined, while the remaining ones were used for DNA preparation and analysis. The section blade was replaced after each specimen block to avoid contamination between samples.

All HPV testing was done at the Ludwig Institute for Cancer Research, São Paulo Branch. Twelve cases were excluded: 6 due to lack of enough representative neoplastic areas in the block after histopathological evaluation and 6 because they were $\beta$-globin-negative. The 74 analysed cases consisted of 18 CIN III, 48 squamous cell carcinomas, 4 adenocarcinomas, 1 adenosquamous carcinoma and 3 undifferentiated carcinomas.

DNA was extracted according to the protocol developed by Pinto and Villa (1998). Samples were initially digested with proteinase K $(200 \mu \mathrm{g} / \mathrm{ml})$, followed by DNA purification using the Glass Max DNA Isolation Spin Cartridge System (GIBCO/BRL Gaithesburg, Maryland, USA), an ion exchange column. After purification, the samples were submitted to PCR with $\beta$-globin primers G73 (5'GAAGAGCCAAGGACAGGTAC-3') and G74 (5'CAACTTCATCCACGTTCACC-3') resulting in a 268 base pair amplicon to exclude false-negative results, serving as an internal control to evaluate the integrity and sufficiency of the DNA present in the sample (Greer et al. 1991). For detection of HPV-DNA, general primers GP5+ (5' TTTGTTACTGTGGTAGATACTAC-3') and GP6+ (5' GAAAAATAAACTGTAAAT CATATTC 3') were used to amplify a fragment of about $150 \mathrm{bp}$ (de Roda Husman et al. 1995, Pinto \& Villa 1998). PCR products were typed with dot-blot hybridization using probes $16,18,31,33,45$, $54,6 / 11,42 / 43 / 44,51 / 52,56 / 58$ labeled with $\mathrm{P}^{32}$ ( $\left.\gamma \mathrm{ATP}\right)$.

\section{RESULTS}

The mean age of the patients was 49.1 years, ranging from 27 to 83 years. The majority of women (76\%) were aged between 31 and 60 years.

The total prevalence of HPV for all cases included was $76 \%$. HPV 16 was the most frequently recognized type, followed by HPV types 33, 18 and 31. The prevalence of untyped HPV with probes used in this study was $6 \%$. Taking only squamous cell carcinoma cases into account,
HPV prevalence was $79 \%$, and the prevalence rate of HPV types was the same for the total number of cases. Sixtyone percent of the patients with CIN III were positive for HPV-DNA and HPV 16 was the most prevalent. Four cases of adenocarcinomas were positive for HPV-DNA, three of these were type 16 and one was type 18 . Three cases of undifferentiated carcinomas were positive for HPV-DNA, two of these were positive for type 16. The single case of adenosquamous carcinoma was negative for HPV-DNA (Table I).

Taking only HPV-DNA positive cases into consideration, HPV 16 was detected in $71 \%$ of squamous cell carcinomas and in $73 \%$ of the total number of cases. These rates were over five times higher than HPV type 33, which was the second most frequent type found (Table II).

\section{TABLE II}

Frequency of specific types in positive papillomavirus cases

\begin{tabular}{lrrrr}
\hline HPV & \multicolumn{2}{c}{ Squamous } & \multicolumn{2}{c}{ Total } \\
& $\mathrm{n}$ & $(\%)$ & $\mathrm{n}$ & $(\%)$ \\
\hline 16 & 27 & $(71)$ & 41 & $(73)$ \\
33 & 5 & $(13)$ & 6 & $(11)$ \\
Untypedd & 3 & $(8)$ & 4 & $(7)$ \\
18 & 2 & $(5)$ & 3 & $(5)$ \\
31 & 1 & $(3)$ & 2 & $(4)$ \\
\hline Total & 38 & $(100)$ & 56 & $(100)$ \\
\hline
\end{tabular}

\section{DISCUSSION}

The International Biological Study on Cervical Cancer showed HPV 16 as the most prevalent HPV type in all countries with the exception of Indonesia, where HPV 18 was the most prevalent type. There were significant geographical variations in the prevalence of less common types of HPV. A clustering of HPV type 45 was apparent in Western Africa, while HPV 39 and 59 were almost entirely confined to Central and South America. The five most prevalent HPV types in Central and South America are 16, 18, 45, 31 and 33 (Bosch et al. 1995).

TABLE I

Prevalence of papillomavirus types according to histopathologic diagnoses

\begin{tabular}{|c|c|c|c|c|c|c|c|c|c|c|}
\hline $\begin{array}{l}\text { Human } \\
\text { papillomavirus }\end{array}$ & $\begin{array}{c}\mathrm{C} \\
\text { intra } \\
\text { neop } \\
\mathrm{n}\end{array}$ & $\begin{array}{l}\text { rvical } \\
\text { pithelial } \\
\text { asia III } \\
(\%)\end{array}$ & $\begin{array}{l}\text { Squar } \\
\text { carci } \\
\mathrm{n}\end{array}$ & $\begin{array}{l}\text { ousc- } \\
\text { loma } \\
(\%)\end{array}$ & $\begin{array}{c}\text { Adenocarcinoma } \\
\text { carcinoma } \\
\text { n }(\%)\end{array}$ & $\begin{array}{c}\text { Adenosquamous } \\
\text { carcinoma } \\
\text { n }(\%)\end{array}$ & $\begin{array}{l}\text { Undiffe } \\
\text { car } \\
n\end{array}$ & $\begin{array}{l}\text { entiated } \\
\text { noma } \\
(\%)\end{array}$ & \multicolumn{2}{|c|}{$\begin{array}{l}\text { Total } \\
\mathrm{n} \quad(\%)\end{array}$} \\
\hline 16 & 9 & 50 & 27 & 56 & $\begin{array}{ll}3 & 75\end{array}$ & - & 2 & 67 & 41 & 56 \\
\hline 33 & 1 & 6 & 5 & 10 & - & - & - & - & 6 & 8 \\
\hline Untyped & - & - & 3 & 6 & - & - & 1 & 33 & 4 & 6 \\
\hline 18 & - & - & 2 & 4 & 125 & - & - & - & 3 & 4 \\
\hline 31 & 1 & 6 & 1 & 2 & - & - & - & - & 2 & 3 \\
\hline HPV positive & 11 & 61 & 38 & 79 & $4 \quad 100$ & - & 3 & 100 & 56 & 76 \\
\hline HPV negative & 7 & 39 & 10 & 21 & - & 1100 & - & - & 18 & 24 \\
\hline Total & 18 & 100 & 48 & 100 & $4 \quad 100$ & 1100 & 3 & 100 & 74 & 100 \\
\hline
\end{tabular}


Table III summarizes HPV prevalence in invasive cervical cancer from cities of each Brazilian region, including results of the present study. The most prevalent HPV is type 16 (Cavalcanti et al. 1994, Eluf-Neto et al. 1994, Bosch et al. 1995, Noronha et al. 1999, Lorenzato et al. 2000). HPV 18 is the second most prevalent HPV type in the North, Belém city (Noronha et al. 1999), Southeast, São Paulo city (Eluf-Neto et al. 1994) and South, Porto Alegre city (Bosch et al. 1995) and it is the third type in the Northeast, Recife city (Lorenzato et al. 2000) and Central Brazil, Goiânia city. The second most prevalent HPV in the Northeast (Lorenzato et al. 2000) is type 31 and in the Central region it is type 33. Although HPV 45 is the third most prevalent type in Central and South America, it was detected only in the Southern region of Brazil (Bosch et al. 1995).

Data collected from the five continents showed that HPV 33 is the fourth or fifth most prevalent type (Bosch et al. 1995), while it was the second most prevalent type in Goiânia.

The distribution of specific HPV types was similar in squamous cell carcinomas and in the total number of cancer cases, since the former was the most frequent histopathologic cancer detected. All cases of adenocarcinomas included in this study were HPV-DNA positive. Despite the small number of cases, HPV 18 was detected in one case and HPV 16 in 3 cases. Adenocarcinomas are less prevalent than squamous cell carcinomas, thus limiting comparison of prevalence rates between these histologic types (Zehbe \& Wilander 1997).

In this study, the viral type failed to be identified in four cases by the same probes utilized to identify most high-risk types. Untyped HPV was a relatively common finding in a large longitudinal investigation of the natural history of HPV infection and cervical neoplasia in a low income female patient population from São Paulo (Franco et al. 1999). It is particularly interesting to observe whether the distribution of HPV types reflects virus prevalence in women whose cytologic examination is normal (Bosch et al. 1995). The actual oncogenic potential of many types of $\mathrm{HPV}$, including new and rare ones, is still unknown, due to the limited number of cases associated with neoplasms
(Meyer et al. 1998). The identification of HPV types in cervical carcinomas indicates that oncogenic HPV may be present among these rare HPV types (Bosch et al. 1995, Meyer et al. 1998).

The total prevalence of HPV was $76 \%$. These results were similar to studies conducted by Baay et al. (1996), Unger et al. (1998) and Noronha et al. (1999) who detected HPV in $87.6 \%, 65 \%$, and $70.3 \%$ of patients with invasive cervical cancer, respectively. These authors used stored formalin-fixed and paraffin-embedded tumor tissues for PCR analysis. Although variables such as type of fixative, fixation time and type of primer had been controlled, and despite the fact that the blocks were recently prepared, it is possible that HPV-DNA prevalence was not completely measured.

Studies have reported difficulties in reproducing PCR results with formalin-fixed and paraffin-embedded tumor tissues (Ben-Ezra et al. 1991, Bianchi et al. 1991, Thompson \& Rose 1991, Goodrow et al. 1992). It was observed that studies using fresh tissue samples commonly report HPV prevalences well over 90\% (Bosch et al. 1995, Karisen et al. 1995, Walboomers et al. 1999). Therefore, it is possible that if fresh frozen tumor tissues had been examined, HPV prevalence might have been higher, since amplification could be hampered by formalin fixation (Baay et al. 1996). Levi et al. (1998) detected higher prevalence of HPV in fresh samples than paraffin-embedded tissues in cases of penile carcinomas.

Moreover, recent studies have suggested a few possibilities to explain the occurrence of false-negative results mainly in high-grade squamous intraepithelial lesions and invasive cervical cancers. The linear integration of the circular HPV genome in the host cell's chromosome can affect the PCR target region. Although the preferential site of disruption is the E2 region, in some cases the primer sequences may coincide with the disrupted regions in the L1 region and this may affect HPV detection. According to Walboomers et al. (1999), the occurrence of false-negative results is due to the integration events affecting L1 sequences that occur with different HPV types.

TABLE III

Prevalence of papillomavirus types in invasive cervical cancer in cities of each Brazilian region

\begin{tabular}{|c|c|c|c|c|c|c|c|c|c|}
\hline \multicolumn{2}{|c|}{$\begin{array}{c}\text { Central }^{a} \\
\text { n } 56\end{array}$} & \multicolumn{2}{|c|}{$\begin{array}{c}\text { South } \\
\text { n } 46\end{array}$} & \multicolumn{2}{|c|}{$\begin{array}{c}\text { Southeast }^{c} \\
\mathrm{n} 186\end{array}$} & \multicolumn{2}{|c|}{$\begin{array}{l}\text { North }{ }^{d} \\
\text { n } 147\end{array}$} & \multicolumn{2}{|c|}{$\begin{array}{c}\text { Northeast } \\
\text { n } 59\end{array}$} \\
\hline Type & $\%$ & Type & $\%$ & Type & $\%$ & Type & $\%$ & Type & $\%$ \\
\hline 16 & 57.1 & 16 & 52.2 & 16 & 53.8 & 16 & 43.5 & 16 & 59.3 \\
\hline 33 & 8.9 & 18 & 8.7 & 18 & 8.6 & 18 & 8.2 & 31 & 11.9 \\
\hline 18 & 5.4 & 31 & 4.3 & $31 / 33$ & 3.2 & Pool & 13.6 & 18 & 5.1 \\
\hline 31 & 1.8 & 45 & 4.3 & Untyped & 18.8 & Untyped & 6.8 & 33 & 5.1 \\
\hline Untyped & 7.1 & Others & 17.4 & & & & & Others & 8.5 \\
\hline $\begin{array}{l}\text { Any HPV } \\
\text { positive }\end{array}$ & 79 & $\begin{array}{l}\text { Any HPV } \\
\text { positive }\end{array}$ & 87 & $\begin{array}{l}\text { Any HPV } \\
\text { positive }\end{array}$ & 84.4 & $\begin{array}{l}\text { Any HPV } \\
\text { positive }\end{array}$ & 70.3 & $\begin{array}{l}\text { Any HPV } \\
\text { positive }\end{array}$ & 89.8 \\
\hline $\begin{array}{l}\text { HPV } \\
\text { negative }\end{array}$ & 21 & $\begin{array}{l}\text { HPV } \\
\text { negative }\end{array}$ & 13 & $\begin{array}{l}\text { HPV } \\
\text { negative }\end{array}$ & 15.6 & $\begin{array}{l}\text { HPV } \\
\text { negative }\end{array}$ & 29.7 & $\begin{array}{l}\text { HPV } \\
\text { negative }\end{array}$ & 10.2 \\
\hline
\end{tabular}

$a$ : current study; $b$ :Bosch et al. 1995; $c$ :Eluf-Neto et al. 1994; $d$ : Noronha et al. 1999; $e$ : Lorenzato et al. 2000 
Other possible factors to consider, although rare, are genotypes that show less amplification efficiency, which are not detectable by the currently used primers (Kleter et al. 1998).

Although the prevalence detected was lower in comparison to data from Walboomers et al. (1999), this study provided knowledge about the prevalence of specific HPV types in CIN III and invasive cervical cancer patients from Goiás (Central Brazil). This information is relevant because specific HPV types may pose different relative risks for cancer. Moreover, the identification of HPV types which are most commonly associated with cervical cancer in different regions has implications for cancer prevention strategies, including the development of effective vaccines.

\section{ACKNOWLEDGMENTS}

To the Medical staff of the Araújo Jorge Hospital, especially Dr Vasco Martins Cardoso, for providing the tumor samples, and Marlene Cavalcanti da Costa for sample handling. To the Virology Group of Ludwig Institute for Cancer Research, for technical assistence in HPV detection and typing. SH Rabelo was the recipient of a fellowship from the School of Pharmacy, Federal University of Goiás

\section{REFERENCES}

Baay MFD, Quint WGV, Koudstall J, Hollema H, Duk JM, Burger MPM, Stoltz E, Herbrink P 1996. Comprehensive study of several general and type-specific primer pair for detection of human papillomavirus DNA by PCR in paraffin-embedded cervical carcinomas. J Clin Microbiol 34: 745747.

Ben Ezra J, Johnson DA, Rossi J, Cook N, Wu, A 1991. Effect of fixation on the amplification of nucleic acids from paraffin-embedded material by yhe polymerase chain reaction. J Histochem Cytochem 39: 351-354.

Bianchi AB, Navone NM, Conti CJ 1991. Detection of loss of heterozygosity in formalin-fixed paraffin embedded tumor specimes by the polymerase chain reaction. Am J Pathol 138: 279-284.

Bosch FX, Manos MM, Munoz N, Sherman M, Jansen AM, Peto J, Schiffman MH, Moreno V, Kurman R, Shah KV 1995. Prevalence of human papillomavirus in cervical cancer: a worldwide perspective. International biological study on cervical cancer (IBSCC). J Natl Cancer Inst 87: 796-802.

Brasil 2001. Estimativas da Incidência e Mortalidade por Câncer, Ministério da Saúde, Instituto Nacional do Câncer, Rio de Janeiro, 86 pp.

Cavalcanti SM, Frugulhetti IC, Passos MR, Fonseca MF, Oliveira LH 1994. Prevalence of human papillomavirus DNA in female cervical lesions from Rio de Janeiro, Brazil. Mem Inst Oswaldo Cruz 89: 575-580.

Cavalcanti SM, Zardo LG, Passos MR, Oliveira LH 2000. Epidemiological aspects of human papillomavirus infection and cervical cancer in Brazil. J Infect 40: 80-87.

de Roda Husman AM, Walboomers JMM, van de Brule AJC, Meijer CJLM, Snijders PJF 1995. The use of general primers GP5 and GP6 elongated at their 3' ends with adjacent highly conserved sequences improves human papillomavirus detection by PCR. J Gen Virol 76:1057-1062.

Eluf-Neto J, Booth M, Munõz N, Bosch FX, Meijer CJLM, Walboomers JM 1994. Human papillomavirus and invasive cervical cancer in Brazil. Br J Cancer 69: 114-119.

Franco EL, Villa LL, Sobrinho JP, Prado JM, Rousseau MC, Désy M, Rohan TE 1999. Epidemiology of acquisition and clearance of cervical human papillomavirus infection in women from a high-risk area for cervical cancer. J Infect Dis 180: 1415-1423.

Gonçalves MA, Massad E, Burattini MN, Villa LL 1999. Relationship between human papillomavirus (HPV) genotyping and genital neoplasia in HIV-positive patients of Santos City, São Paulo, Brazil. Int J STD AIDS 10: 803-807.

Goodrrow, TL, Prahalada SR, Storer RD, Manam SV, Leander KR, Kraynak AR, van Zwieten MJ, Nichols WW, Bradley MO 1992. Polymerase chain reaction/sequencing analysis of ras mutations in paraffin embedded tissues as compared with $3 \mathrm{~T} 3$ transfection and polymerase chain reaction/sequencing of frozen tumor deoxiribonucleic acids. Lab Invest 66: 504-511.

Greer CE, Peterson SL, Kiviati NB, Manos M 1991. PCR amplification from paraffin-embedded tissues. Effect of fixative and fixation time. Am J Clin Pathol 95: 117-124.

Karisen F, Kristensen G, Holm R, Chitemerere M, Berner A, Hagmar BM 1995. High incidence of HPV in 146 cervical carcinomas. A study using three different pairs of consensus primers also detecting viral genomes with putative deletions. Eur J Cancer 31 A: 1511-1516.

Kleter B, Jan Vandorn L, Schegget JT, Schrauwen L, Krimpen KV, Burger M, Harmsel BT, Quint W 1998. Novel shortfragment PCR assay for highly sensitive broad spectrum detection of anogenital human papillomavirus. Am J Pathol 153: 1731-1739.

Levi JE, Rahal P, Sarkis AS, Villa LL 1998. Human papillomavirus DNA and p53 status in penile carcinomas. Int J Cancer 76: 779-783.

Lorenzato F, Ho L, Terry. G, Singers A, Santos LC, De Lucena Batista R, Lubambo T 2000. The use of human papillomavirus typing in detection of cervical neoplasia in Recife (Brazil). Int J Gynecol Cancer 10: 143-150

Meyer T, Arndt R, Christophers E, Beckmann ER, Schroder S, Gissmann L, Stockfleth E 1998. Association of rare human papillomavirus types with genital premalignant and malignant lesions. J Infect Dis 178: 252-255.

Noronha V, Mello W, Villa LL, Macedo R, Bisi F, Mota R, Sassamoto K, Monteiro T, Linhares, A 1999. Human papillomavirus associated with uterine cervix lesions. Rev Soc Bras Med Trop 32: 235-240.

Pinheiro NA, Villa LL 2001. Low frequency of p53 mutations in cervical carcinomas among Brazilian women. Braz J Med Biol Res 34: 727-733.

Pinto AP, Villa LL 1998. A spin cartridge system for DNA extraction from paraffin-embedded tissues. Mol Pathol 51: 48-49.

Syrjanen KJ, Syrjanen SM 2000. Diagnostic techniques in HPV detection. In Papillomavirus Infections in Human Pathology, Jonh Wiley \& Sons, Chichester, p. 89-115.

Thompson CH, Rose BR 1991. Deleterious effects of formalin/ acetic acid/alcohol (FAA) fixation the detection of HPV DNA by in situ hybridization and the polymerase chain reaction. Pathology 23: 327-330.

Unger ER, Vernon SD, Lee DR, Miller DL, Reeves WC 1998. Detection of human papillomavirus in archival tissues: comparison of in situ hybridization and polymerase chain reaction. J Histochem Cytochem 46: 535-540.

Walboomers JM, Meijer CJLM 1997. Do HPV negative cervical carcinomas exist? J Pathol 181:253-254.

Walboomers JM, Jacobs MV, Manos MM, Bosch FX, Kummer JA, Shah KV, Snijders PJ, Peto J, Meijer CJ, Munoz N 1999. Human papillomavirus is a necessary cause of invasive cervical cancer worldwide. J Pathol 189: 12-19.

Zehbe I, Wilander E 1997. Human papillomavirus infection and invasive cervical neoplasia: a study of prevalence and morphology. J Pathol 181: 270-275. 